\title{
Effect of intrauterine infusion of Momordica charantia L. on oxidative stress and pregnancy rate in infertile cows
}

\author{
Birten Emre ${ }^{1}$, Ömer Korkmaz ${ }^{1}$, Füsun Temamoğulları ${ }^{2}$, Abuzer Kafar Zonturlu ${ }^{1}$, \\ İsmail Koyuncu ${ }^{3}$, Mustafa Özkaraca ${ }^{4}$, Mehmet Cengiz $^{5}$ \\ ${ }^{1}$ Department of Obstetrics and Gynecology, ${ }^{2}$ Department of Pharmacology and Toxicology, \\ ${ }^{3}$ Department of Biochemistry, Faculty of Medicine, \\ Harran University, 63200 Şanlıurfa, Turkey \\ ${ }^{4}$ Department of Pathology, ${ }^{5}$ Department of Obstetrics and Gynecology, \\ Faculty of Veterinary Medicine, Atatürk University, 25240 Erzurum, Turkey \\ birten@gmail.com
}

Received: August 2, $2017 \quad$ Accepted: December 4, 2017

\begin{abstract}
Introduction: The effect of intrauterine administration of Momordica charantia L. (MC) extract on oxidative changes and pregnancy rate in infertile cows was investigated. Material and Methods: Endometrial smear specimens were taken from 40 cows with fertility problems for cytological examination, and the cows were randomly divided into two groups: group I $(n=20)$ was subjected to intrauterine administration of $40 \mathrm{~mL}(0.25 \mathrm{~g} / \mathrm{mL})$ of MC extract, group II $(\mathrm{n}=20)$ was subjected to intrauterine administration of $40 \mathrm{~mL}$ of pure olive oil. Blood samples were taken starting from the day of administration of MC extract or olive oil (day 0) and then for three weeks at weekly intervals (days 7, 14, 21). Blood serum samples were evaluated for total antioxidant capacity (TAS), total oxidant level (TOS), oxidative stress index (OSI), lipid hydroperoxide (LOOH), and nitric oxide (NO) levels. In addition, on the $14^{\text {th }}$ day following treatment, two doses of PGF $2 \alpha$ were administrated to all cows at 14-day intervals. Following the second PGF2 $\alpha$ administration, insemination and GnRH administration was performed at the $60^{\text {th }} \mathrm{h}$ after PGF2 $\alpha$ treatment. Smear samples were stained with Giemsa and immunohistochemically to determine cytological changes and inflammatory status. Results: According to cytological findings, subclinical endometritis was a prevalent disorder in cows with infertility problem $(82.5 \%$; 33/40). Additionally, $60.6 \%(20 / 33)$ of the cows with subclinical endometritis had acute inflammation, whereas remaining 13 cows had chronic endometritis. Of the cows with subclinical endometritis, 50\% (8/16) and $35 \%(6 / 17)$ became pregnant in group I and II, respectively $(\mathrm{P}>0.05)$. Although the oxidative stress parameters showed similarities between both groups $(\mathrm{P}>0.05)$, there was a significant difference $(\mathrm{P}<0.001)$ between the groups in terms of mean $\mathrm{NO}$ and LOOH levels (NO $-31.20 \pm 11.38 v s 44.53 \pm 11.50 \mu \mathrm{mol} / \mathrm{L}$ and $\mathrm{LOOH}-1.22 \pm 0.37 v s 1.89 \pm 0.36 \mu \mathrm{mol} / \mathrm{L}$ ). Conclusion: The obtained results indicated that $\mathrm{MC}$ administration, especially in the presence of active inflammation, may improve the pregnancy rate by positive reduction of oxidative changes.
\end{abstract}

Keywords: cow, infertility, subclinical endometritis, Momordica charantia L., oxidative stress.

\section{Introduction}

Infertility is one of the biggest problems affecting reproductive performance in dairy cow enterprises. Infertility in cows leads to economic loss by bringing together many factors such as the prolongation of the period between calving and repetitive pregnancy, inability to obtain offspring, reduction in milk production and income from milk, unnecessary feeding of infertile animals, and use of extra labour force (51). Endometritis, one of the important aetiological factors of infertility, causes serious problems in reproductive efficiency in cows $(18,27)$. Bacteria play an important role in the aetiology of endometritis. Inability to complete bacterial elimination, especially after birth, leads to infection. Endometritis has an acute or chronic 
course and may be observed in both clinical and subclinical forms (2). Subclinical endometritis (SCE) refers to the inflammation of the endometrium that can only be determined by cytological examination (49).

In the treatment of uterine infections in cows, hormones, antibiotics or astringents, enzymes, and phytotherapeutic substances are used (44). The clinical treatment rates and their efficacy associated with reproductive performance are controversial (21). However, although the treatment methods mentioned above are generally used in the treatment of clinical endometritis, there is no generally accepted treatment method for subclinical cytologic endometritis (44). As an alternative therapy for antibiotic infusion in endometritis, a wide range of chemical agents including hyperimmune serum (1), autologous plasma, E. coli lipopolysaccharides (47), pre-acetic acid containing drugs (26), and irritant solutions containing antiseptics (33), or antioxidants (28) are proposed.

Momordica charantia L. (MC) is a perennial climbing plant from the family of Cucurbitaceae and is known by the names of balsam pear, parpara, and bitter melon. In studies conducted with $\mathrm{MC}$ cultures that grow in many tropic and subtropic regions of the world, it has been demonstrated that MC has antihyperglycemic (45), antiulcer (20), antifungal (54), antimicrobial, immunotoxic, antiviral, antimutagenic, antifertility, antidiabetic (30) antioxidant effects (32), and protein synthesis inhibitory activity (38).

All inflammatory reactions which occur in organism cause oxidative stress (OS) at cellular, tissue, and organ levels. The stress is defined as the disruption of the balance between oxidants and antioxidants at cellular or individual level leading to damage to macromolecules (lipids, proteins, and DNA) and impairment of normal metabolism and physiology (36, 52). OS in dairy cow is involved in the aetiopathogenesis of diseases (36) and reproductive problems (12). The adverse effects of oxidant molecules on reproductive function can be classified as inhibition of sperm and oocyte fusion, embryonic death, and endometritis (3). Various parameters such as lipid hydroperoxide (LOOH), total oxidant level (TOS), oxidative stress index (OSI), total antioxidant capacity (TAS), and nitric oxide (NO) levels are used in assessing the severity of oxidative stress.

The present study aimed to determine the effects of intrauterine infusion of oily homogenised MC on chosen oxidative stress parameters and pregnancy rate in lactating infertile cows.

\section{Material and Methods}

Animal material. The study was carried out on 40 Holstein-Friesian cows, which had no abnormality (anovulation, delayed ovulation and hazy, mucopurulent, purulent vaginal discharge) in the gynecological examinations, had at least one birth, aged between three and eight years, had a body condition score (BCS) ranging from 2.75 to 4.5, according to the 5-point scale reported by Edmonson et al. (15), had the last lactation (305 days) milk yield of an average of $7,320 \mathrm{~kg}(5,185-8,540 \mathrm{~kg})$, had an average postpartum period of 179 days (106-347 days), and had no other clinical conditions other than infertility.

Study order. For the selection of cows without clinical endometritis and ovarian problems, gynecological examination was performed by means of the inspection of the vulva, tail, and perineum, rectal palpation, vaginoscopy, and ultrasonography. Endometrial smear specimens were obtained from cows without clinical and anatomical abnormalities.

Cytological sampling and evaluation. Since cytopathological examination was accepted as the better diagnostic method for subclinical endometritis, bacteriological examination was not performed. Cytological sampling from cows with fertility problems was performed using endocervical brush as reported by Kasimanickam et al. (27), and endometritis in cows was confirmed by the cytological examination. Smear samples were stained with the Giemsa method to determine inflammatory cells. Evaluation was performed according to Polat et al. (43). In postpartum cows, a neutrophil ratio of $>5 \%$ or greater was defined as the threshold for SE (37). For this purpose, a cytopathological classification was made according to the presence of polymorphic nuclear cells (PMN) and lymphocytes (LYM) to determine the inflammatory state (acute if PMN $+\mathrm{LYM} \geq 5 \%$ and chronic if LYM $\geq 5 \%$ ). In cytological evaluation, in addition to Giemsa method, immunohistochemical staining was performed to support chronic and acute inflammation findings. The samples were incubated with bovine serum albumin (BSA) solution (1 $\mathrm{g}$ of BSA was added and dissolved in $100 \mathrm{~mL}$ of PBS) for $20 \mathrm{~min}$. Smear samples were incubated with CD3 (Sigma, USA, dilution ratio: 1/200) and IFNy (AbdSerotec, Thailand, dilution ratio: $1 / 300$ ) primary antibodies for $20 \mathrm{~min}$ in order to identify $\mathrm{T}$ lymphocytes and to determine the acute inflammation. Mouse and Rabbit Specific HRP/DAB Detection IHC Kit (Abcam, USA) was used secondarily. The sections were counterstained with Mayer's haematoxylin. The tissues covered with Entellan were examined under light microscope. The ratio of immunopositive lymphocytes seen in the field to all lymphocytes was evaluated.

Preparation of plant extract. Momordica charantia's ripe fruits were gathered around Adana, Tarsus, and Mersin (Turkey) from 2014 to 2015. The identification of the plant was made by the Department of Pharmacology and Toxicology, Faculty of Veterinary Medicine, Harran University. In accordance with the method used in traditional medicine, MC extract was obtained by keeping ripe fruit of plant $(250 \mathrm{~g})$ in olive oil ( $1 \mathrm{~L})$ for 15 days at room temperature and then crushing them with this olive oil 
(9). MC contains biologically active components including phenolic compounds, triterpene glycoside, vitamins, and minerals (19), protein and steroids (41), polysaccharides such as glucose, galactose, arabinose, rhamnose, and mannose (42), and saponin (39). The density of the resulting mixture was calculated to be $0.25 \mathrm{~g} / \mathrm{mL}$.

Grouping, drug administration, oestrus synchronisation, and artificial insemination. Infertile cows without any pathological problems in the clinical examination were randomly divided into two groups regardless of the results of the cytological examination. Cows $(\mathrm{n}=20)$ in group I were treated with $40 \mathrm{~mL}$ $(0.25 \mathrm{~g} / \mathrm{mL})$ of MC extract, while cows $(\mathrm{n}=20)$ in group II received $40 \mathrm{~mL}$ of pure olive oil. Both solutions were applied by intrauterine route following to catheterisation under aseptic conditions.

In addition, on the $14^{\text {th }}$ day following treatment, double-dose of PGF2 $\alpha$ (25 mg, intramuscularly, Dinoprost tromethamine, Dinolytic, Pfizer, Turkey) was administered to all cows at 14-day intervals. Following the second PGF $2 \alpha$ administration, insemination was performed and single dose of $\mathrm{GnRH}$ (10 $\mu \mathrm{g}$; intramuscularly; Buserelin asetat, Receptal, Intervet, Turkey) was administered at the $60^{\text {th }} \mathrm{h}$ after PGF $2 \alpha$ treatment, without following oestrus symptoms. However, Graffian follicle with a diameter greater than $16 \mathrm{~mm}$ was observed in all inseminated cows. Reinsemination was not performed although oestrus signs continued. Ovulation was not detected in any cow by the ultrasonographic examinations performed $24^{\text {th }} \mathrm{h}$ after insemination. Pregnancy examination was performed by ultrasonography (Pie Medical, 100 Falco Vet, 6-8 MHz Linear probe) 30-45 days after the insemination. Pregnancy rate $(\%)$ obtained in the first insemination was evaluated as fertility parameter.

Collection of blood samples. In all groups, $10 \mathrm{~mL}$ blood samples were taken from the coccygeal vein into $10 \mathrm{~mL}$ vacuum, anticoagulant-free glass tubes, starting from the day of the start of treatment (day 0), for three weeks at weekly intervals (days $7,14,21$ ) to determine the blood levels of oxidative stress parameters. The samples were centrifuged at 3,000 rpm for $15 \mathrm{~min}$ and serum fractions were separated. The separated serum fractions were transferred to Eppendorf tubes and stored at $-20^{\circ} \mathrm{C}$ until measurements.

Determination of levels of oxidative stress parameters. The levels of oxidative stress parameters were determined using ELISA kits by spectrophotometric method in the Harran University, Faculty of Medicine, Department of Biochemistry.

Serum TAS levels were determined by means of available diagnostic kits (Rel Assay, Gaziantep, Turkey). According to this method, $\mathrm{Fe}^{2+}$ o-dianisidine complex enters the Fenton-type reaction with hydrogen peroxide to form the $\mathrm{OH}$ radical. These strongly reactive oxygen species react with the colourless o-dianisidine molecule at low $\mathrm{pH}$ to form yellowbrown dianisidyl radicals. O-dianisidyl radicals participate in advanced oxidation reactions to increase colour formation. However, the antioxidants in the samples inhibit the colour formation by suppressing the oxidation reactions. After the samples were read spectrophotometrically, the results were calculated as $\mu \mathrm{mol}$ Trolox equiv/L (13).

Serum TOS levels were determined by means of available diagnostic kits (Rel Assay, Gaziantep, Turkey). According to this method, the oxidants present in the serum convert the ferrous ion to the ferric ion. Ferric ions form a coloured complex with xylenol orange in acidic environment. Glycerol in the medium accelerates this reaction. The intensity of the colour associated with the amount of oxidants present in the serum was measured spectrophotometrically (14). $\mathrm{H}_{2} \mathrm{O}_{2}$ was used as a standard and the results were calculated as $\mu \mathrm{mol} \mathrm{H}_{2} \mathrm{O}_{2}$ equiv/L (23).

For calculation of OSI which is an indicator of oxidative stress, firstly TOS and TAS units were calculated. Oxidative stress index was calculated according to the following formula: OSI (arbitrary units $)=\operatorname{TOS}\left(\mu \mathrm{mol} \mathrm{H}_{2} \mathrm{O}_{2}\right.$ equiv/L)/TAS $(\mu \mathrm{mol}$ Trolox equiv/L) $\times 100(6)$.

Total peroxide concentrations were determined using the "FOX ${ }_{2}$ " method (5) with minor modifications. Total peroxide content of plasma samples was determined as a function of the absorbance difference between test and blank tubes using a solution of $\mathrm{H}_{2} \mathrm{O}_{2}$ as standard. The coefficient of variation for individual plasma samples was less than $5 \%$.

The measurement was performed according to the Nitrate/Nitrite Colorimetric Assay Kit/Cayman Chemical kit protocol (USA).

Statistical analysis. The study was replicated four times. Results were expressed as the mean \pm standard deviation. Weekly changes in antioxidants means were analysed with General Linear Models-Repeated measures test to determine significant differences in all the parameters between groups. Pregnancy rates were analysed with chi-square test. Statistical analysis of the results was performed using SPSS (Statistical Package for the Social Sciences, 16.0).

\section{Results}

Cytological findings. The incidence of SCE was determined in $82.5 \%$ of the cases $(33 / 40)$ in cytological examinations in infertile cows with no vaginal discharge at the vaginal examination. Cytopathologically, SCE was classified as healthy, acute, and chronic according to the cell evaluation results. The cytological samples, which presented endometrial prismatic cells, which were natural cell type of endometrial epithelial lining, were confirmed as ''healthy'. In cows with acute endometritis, there was a dense neutrophil presence along with prismatic epithelium. In the group of cows with chronic 
endometritis, lymphocytes were found to be high in number, and neutrophils were frequently observed in these cases. Acute inflammation was detected in $60.6 \%(20 / 33)$ of infertile cows with cytological endometritis, whereas others had chronic inflammation $(13 / 33 ; 33.3 \%)$. The rates of acute $(55 \%, \mathrm{n}=11 ; 45 \%, \mathrm{n}=9)$ and chronic endometritis $(25 \%, \mathrm{n}=5 ; 40 \%, \mathrm{n}=8)$ were determined in group I and group II, respectively. In the study, no endometritis was detected in two samples $(10 \%)$ in both groups, and three cytological specimens (7.5\%) were excluded from evaluation because of poor quality of smears (Table 1).

Pregnancy rate. Pregnancy rates after intrauterine inoculation of MC extract and pure olive oil infusion in infertile cows were found to be $55 \%$ and $35 \%$ in group I and group II, respectively
$(\mathrm{P}>0.05)$. The comparison of cows with cytologic endometritis alone within the groups revealed a pregnancy rate of $50 \%(8 / 16)$ and $35.3 \%(6 / 17)$, respectively. Pregnancy rates in cows which were detected to have acute inflammation were $54.5 \%$ $(6 / 11)$ and 33.3\% (3/9), respectively $(\mathrm{P}>0.05)$. Pregnancy rates in cows that were determined to have stimulated T lymphocyte activity with the presence of CD3 were $40 \%(2 / 5)$ and $37.5 \%(3 / 8)$, respectively (Table 1).

Oxidative changes. Although the oxidative stress parameters showed similarities between groups $(\mathrm{P}>0.05)$, there was a significant difference between groups in terms of mean $\mathrm{NO}$ and $\mathrm{LOOH}$ levels $(\mathrm{NO}-31.20 \pm 11.38$ vs $44.53 \pm 11.50 \mu \mathrm{mol} / \mathrm{L}$ and $\mathrm{LOOH}-1.22 \pm 0.37$ vs $1.89 \pm 0.36 \mu \mathrm{mol} / \mathrm{L}$, $\mathrm{P}<0.001)$ (Table 2).

Table 1. Distribution of pregnancy rates according to cytopathological classification

\begin{tabular}{lllll}
\hline Group & $\begin{array}{l}\text { Pregnant/acute SCE } \\
(\mathrm{n})\end{array}$ & $\begin{array}{l}\text { Pregnant/chronic SCE } \\
(\mathrm{n})\end{array}$ & $\begin{array}{l}\text { Normal } \\
(\mathrm{n})\end{array}$ & $\begin{array}{l}\text { Not evaluated } \\
(\mathrm{n})\end{array}$ \\
\hline Group I & $6 / 11(54.5 \%)$ & $2 / 5(40 \%)$ & $2 / 2$ & $1 / 2$ \\
Group II & $3 / 9(33.3 \%)$ & $3 / 8(37.5 \%)$ & $1 / 2$ & $0 / 1$ \\
\hline P & $>0.05$ & $>0.05$ & & \\
\hline Total & $9 / 20(45 \%)$ & $5 / 13(38.4 \%)$ & $3 / 4$ & $1 / 3$ \\
\hline
\end{tabular}

$\mathrm{n}$ - number of pregnant cows/total number of cows, SCE - Subclinical endometritis

Table 2. Changes in antioxidant parameters according to days in groups I and II

\begin{tabular}{|c|c|c|c|c|c|}
\hline \multirow{2}{*}{ Parameter } & \multicolumn{5}{|c|}{ Group I $(\mathrm{n}=20)$} \\
\hline & 0 day & 7 days & 14 days & 21 days & Total \\
\hline TAC ( $\mu$ moltroloxeqv./L) & $1.21 \pm 0.33$ & $1.26 \pm 0.11$ & $1.22 \pm 0.32$ & $1.29 \pm 0.33$ & $1.24 \pm 0.27^{\mathrm{a}}$ \\
\hline $\mathrm{TOC}\left(\mu \mathrm{mol} \mathrm{H} \mathrm{O}_{2} \mathrm{Eq} / \mathrm{L}\right)$ & $13.41 \pm 2.84$ & $13.76 \pm 3.63$ & $13.72 \pm 3.85$ & $16.6 \pm 6.94$ & $14.4 \pm 4.31$ \\
\hline OSI (mmol/L-1) & $1.24 \pm 0.5$ & $1.09 \pm 0.28$ & $1.21 \pm 0.47$ & $1.32 \pm 0.53$ & $1.21 \pm 0.44$ \\
\hline $\mathrm{NO}\left(\mu \mathrm{mol} / \mathrm{L}^{-1}\right)$ & $31.3 \pm 9.29^{\mathrm{a}}$ & $29.99 \pm 15.05^{\mathrm{a}}$ & $32.26 \pm 11.18^{\mathrm{a}}$ & $31.27 \pm 10.0^{\mathrm{a}}$ & $31.2 \pm 11.38^{\mathrm{a}}$ \\
\hline \multirow[t]{3}{*}{$\mathrm{LOOH}\left(\mu \mathrm{mol} / \mathrm{L}^{-1}\right)$} & $1.2 \pm 0.62^{\mathrm{a}}$ & $1.23 \pm 0.28^{\mathrm{a}}$ & $1.24 \pm 0.33^{\mathrm{a}}$ & $1.22 \pm 0.25^{\mathrm{a}}$ & $1.22 \pm 0.37^{\mathrm{a}}$ \\
\hline & \multicolumn{5}{|c|}{ Group II $(n=20)$} \\
\hline & 0 day & 7 days & 14 days & 21 days & Total \\
\hline TAC ( $\mu$ moltroloxeqv./L) & $1.55 \pm 0.21$ & $1.52 \pm 0.34$ & $1.46 \pm 0.32$ & $1.36 \pm 0.29$ & $1.47 \pm 0.29^{b}$ \\
\hline $\mathrm{TOC}\left(\mu \mathrm{mol} \mathrm{H} \mathrm{O}_{2} \mathrm{Eq} / \mathrm{L}\right)$ & $11.89 \pm 3.38$ & $12.12 \pm 3.07$ & $11.39 \pm 3.43$ & $13.08 \pm 4.35$ & $15.09 \pm 3.56$ \\
\hline OSI $\left(\mathrm{mmol} / \mathrm{L}^{-1}\right)$ & $0.77 \pm 0.24$ & $0.85 \pm 0.38$ & $0.83 \pm 0.35$ & $0.99 \pm 0.55$ & $0.86 \pm 0.38$ \\
\hline $\mathrm{NO}\left(\mu \mathrm{mol} / \mathrm{L}^{-1}\right)$ & $43.0 \pm 13.75^{b}$ & $42.12 \pm 12.24^{b}$ & $46.2 \pm 10.62^{b}$ & $46.8 \pm 9.42^{b}$ & $44.53 \pm 11.5^{b}$ \\
\hline $\mathrm{LOOH}\left(\mu \mathrm{mol} / \mathrm{L}^{-1}\right)$ & $1.76 \pm 0.42^{b}$ & $1.85 \pm 0.41^{b}$ & $1.89 \pm 0.29^{b}$ & $2.07 \pm 0.32^{b}$ & $1.89 \pm 0.36^{\mathrm{b}}$ \\
\hline
\end{tabular}

TAC - total antioxidant capacity, TOC - total oxidant capacity, OSI - oxidative stress index, NO - nitric oxide, LOOH - lipid hydroperoxide. Results are expressed as mean \pm standard deviation.

${ }^{a, b}$ different letters for a given parameter in the same column means significant difference between groups I and II 


\section{Discussion}

Infertility in dairy cows is one of the most important problems affecting reproduction in the postpartum period, and endometritis has great effects on fertility (18). Subclinical endometritis (18) affects reproduction (48) and causes severe reproductive losses such as a decrease in pregnancy rates and increase in the time between repeated pregnancies and removal from the herd (34). In dairy cows, SCE has a wide distribution range of $12 \%-94 \%(18,27)$. Apaydin et al. (4) reported that $170(87.5 \%)$ of the 190 infertile cows had endometritis. However, Gilbert et al. (18) found that the mean SCE incidence was $53 \%$ on 40 to 60 days postpartum and Kasimanickam et al. (27) found 37\% (80/215) on 20 to 33 days postpartum. In the present study, SCE incidence was found as high as $82.5 \%$ in infertile cows on the $179^{\text {th }}(106-347$ days $)$ day postpartum. It was determined that $60.6 \%(20 / 33)$ of cows with cytological endometritis had acute inflammation, whereas $39.4 \%$ (13/33) had chronic inflammation. The differences in SCE incidence have been attributed to the use of different neutrophil threshold value and diagnostic method, postpartum period in which infection is detected, region, climate, nutritional differences, and management of the study herd (53). In this study, subclinical endometritis was found to be the most important cause of infertility in cows. However, the response to therapeutic interventions in SCE cases has not always been sufficient.

It has been reported that an animal with endometritis has a $20 \%$ lower rate of pregnancy despite treatment compared to healthy animals in the herd (49). This is explained by the time spent over the course of the disease and the permanent damage to the endometrium tissue. LeBlanc et al. (34) reported a reduction of $27 \%$ in total pregnancy rate due to chronic endometritis. Gilbert et al. (18) found that the rate of pregnancy in the first insemination was $11 \%$ in cows with SCE and $36 \%$ in healthy cows, and pregnancy rates were significantly lower in cows with SCE at postpartum day 300 than healthy ones.

The use of essential oils has also been tried in addition to the use of antibiotics and antiseptics in the treatment of endometritis. It has been concluded that essential thyme oil (pregnancy rate 66.6\%) administered intrauterinally can be used as an alternative to conventional medications in the treatment of chronic endometritis (40). Khillare et al. (29) found that intrauterine treatment with mixture obtained from medicinal herbs was more effective and the pregnancy rate was higher in cows with endometritis, metritis, and "repeat breeder" (70\%) than the control group (40\%). Similarly, it was found that the percentage of pregnant cows after the first insemination $(35.7 \%)$ was lower than the animals receiving parenteral treatment (40\%), when Pelargonium sidoides, prepared from plant extracts, was intrauterine administered for three days on days 21 to 27 postpartum in animals with chronic endometritis (7). However, it has been reported that intrauterine treatment with eucalyptus oil failed in experimental mares with endometritis (17). In the present study, it was determined that the pregnancy rate $(45 \%)$ in infertile cows was within the same limits as in other studies. Although the pregnancy rate after treatment was higher in group I (55\%) than in group II (35\%), no statistically significant difference was found between the groups. MC extract was first applied in cows with endometritis in this area. The numerical success achieved in this study suggests that antibacterial, antimycobacterial, antioxidant, and immunomodulatory effects of Momordica charantia L. might have been beneficial.

The success of endometritis treatment can be affected by the degree of endometritis and the time of onset of treatment in the postpartum period. Accordingly, the success rate was $59.5 \%$ for the treatments performed before the $42^{\text {nd }}$ day postpartum, whereas this rate was found to reach $79.6 \%$ for the treatments performed in the following periods. As observed in the present study, the pregnancy rate, especially in the control group, was associated with spontaneous recovery over time. However, based on these findings, it is also emphasised that it is not a reasonable approach to postpone the time of treatment (16). On the contrary, it is advisable to treat as early as possible in cases of subacute and chronic endometritis (25). In mild cases, there is a minimal increase in lymphocyte and plasma cell counts with non-diffuse periglandular fibrosis followed by an improvement, whereas fibrous tissue can develop instead of endometrial tissue in severe cases. In this case, ongoing leukocytosis is seen and uterine tissue thickens due to inflammation and loses its functionality. This degeneration in the uterine gland tissue results in atrophy of the uterine glands and glandular fibrosis (10). In the present study, the pregnancy rate in the cows with acute inflammation was found to be higher than in chronic cases. It is thought that the MC extract can be used for the treatment of acute inflammation. Therefore, it is considered necessary to develop early diagnostic and therapeutic methods and to determine new strategies in order to minimise the loss of productivity in the dairy cows in the postpartum period.

It is stated that SCE may increase OS and can help in the diagnosis and monitoring the effectiveness of the treatment of SCE in cows (31). In some studies, higher NO plasma concentrations were reported in cows with clinical (35) and subclinical endometritis $(31,35)$ than in healthy controls. Li et al. (35) demonstrated that the blood NO concentration was $8.15 \pm 0.97 \mu \mathrm{mol} / \mathrm{L}$ in cows with SCE versus $6.43 \pm 0.93 \mu \mathrm{mol} / \mathrm{L}$ in healthy controls. Similarly, Krishnan et al. (31) identified relatively higher concentrations (81.34 \pm 1.70 and $57.50 \pm 1.36 \mu \mathrm{mol} / \mathrm{L}$ ) in blood, uterine fluid, and tissues. The increase in these values indicates the formation of an oxidative damage due to SCE. 
Following treatment, the reduction in $\mathrm{NO}$ levels indicates anti-inflammatory activity (50). Similarly, Sagor et al. (46) found that MC reduced NO levels in rats receiving carbontetrachloride. In the present study, examination of difference between groups in periods following treatment showed that the mean NO level was lower in group I than in group II $(31.20 \pm 11.38$; $44.53 \pm 11.50 \mu \mathrm{mol} / \mathrm{L}$, respectively). In the present study, examination of difference between groups in periods following treatment showed that the mean NO level was lower in group I than in group II (31.20 \pm 11.38 ; $44.53 \pm 11.50 \mu \mathrm{mol} / \mathrm{L}$, respectively). Examination of weekly changes in group I and group II following treatment showed that NO levels showed similar changes $(\mathrm{P}>0.05)$, and the examination of mean difference between groups did not show any significant difference $(\mathrm{P}>0.05)$.

Lipid peroxidation occurs in response to oxidative stress leading to the formation of lipid hydroperoxides (11). The most significant damage caused by lipid peroxidation, which plays a role in the pathogenesis of various diseases, is observed on the cell membrane (8). The number of studies investigating the effects of endometritis on $\mathrm{LOOH}$ is insufficient. Examination of weekly changes in group I and group II following treatment revealed that LOOH levels showed similar changes $(\mathrm{P}>0.05)$, and the examination of mean difference between groups showed a statistically significant difference $(1.22 \pm 0.37 ; 1.89 \pm 0.36 \mu \mathrm{mol} / \mathrm{L}$, $\mathrm{P}<0.001)$. LOOH levels can be used as a complementary and necessary tool for diagnosis and evaluation of treatment effectiveness. Although previous studies have suggested that TAS, TOS, and OSI values are significantly lower in healthy animals, and are important markers of oxidative damage $(22,24)$, it was demonstrated that post-treatment and pre-treatment levels did not show any significant difference in healthy controls or SCE group. This suggests that the chronicity of local infections may not result in an increase in oxidative stress at a level that is reflected in the overall blood circulation.

The obtained results indicate that subclinical endometritis is an important factor in the development of infertility in cows. Since subclinical endometritis is difficult to diagnose under field conditions, blinded treatments are often used to achieve an outcome. To date, there is no generally accepted approach to the treatment of subclinical endometritis in cows. The present study is the product of this quest. It was demonstrated that the intrauterine administration of MC extract increased the pregnancy rate in cows. Based on the results of our study, it was concluded that the positive effect of MC extract on fertility might have emerged as a result of its antibacterial, immunomodulatory, and healing-promoting effects rather than its antioxidant effect. On the other hand, the examination of the changes in mean LOOH levels suggests that these parameters may be useful for both diagnosis and determining the prognosis of the disease.
However, since this study was carried out on a limited number of cows, the results obtained are preliminary and need to be supported by further studies.

Conflict of Interests Statement: The authors declare that there is no conflict of interests regarding the publication of this article.

Financial Disclosure Statement: This study was financially supported by the Harran University (Project No. 15133).

Animal Rights Statement: In this study, the Ethics Committee report was received before application in accordance with the direction of the Dollvet Inc. Experimental Animals Local Ethics Board (DOLLVET-HADYEK).

Acknowledgements: The authors are thankful to Şükrü Gürler for the help with statistical analysis of the study. The authors are also grateful to the farmers for their cooperation.

\section{References}

1. Ahmadi M.R., Hosseini A., Gheisari H.R., Yavari M.: Preliminary trial in treatment of postpartum endometritis with intrauterine application of hyper immune serum in dairy cows. Asian Pacific J Reprod 2014, 4, 360-365.

2. Alaçam E.: İnekte infertilite sorunu. In: Evcil Hayvanlarda Doğum ve Infertilite, edited by Alaçam E., Second press, Medisan Ankara, Turkey, 1999, pp. 267-288.

3. Anne V.L., Jacquez D.: Oksidative stress and peritoneal endometriosis. Fertil Steril 2002, 77, 861-870.

4. Apaydın A.M., Özer H., Kalkan C., Öcal H., Bostancıoğlu H., Eröksüz Y.: İnfertil ineklerde endometritisin klinik muayene ve biyopsi ile teșhisi üzerine çalışma. Y Y Ü Vet Fak Derg 1991, 2, 81-85.

5. Arab K., Steghens J.P.: Plasma lipid hydroperoxides measurement by an automated xylenol orange method. Anal Biochem 2004, 325, 158-163.

6. Aycicek A., Erel O.: Total oxidant/antioxidant status in jaundiced newborns before and after phototherapy. J Pediatr (Rio de Jeneiro) 2007, 83, 319-322.

7. Bademkiran S., Kurt D., Yokus B., Celik R.: Comparison of Pelargonium sidoides, placebo, and antibiotic treatment of chronic endometritis in dairy cows: a field trial. J Anim Vet Adv 2009, 8, 1242-1247.

8. Basaga H.S.: Biochemical aspect of free radicals. Biochem Cell Biol 1990, 68, 989-998.

9. Baytop T.: Türkiye'de bitkilerle tedavi geçmişte ve bugün. Nobel Tip Kitapevi. Second press, ISBNN 975-420-021-1, 1999, pp. 279-280.

10. Bretzlaff K.: Rationale for treatment of endometritis in the dairy cow. Vet Clin North Am Food Anim Pract 1987, 3, 593-607.

11. Catalá A.: Lipid peroxidation of membrane phospholipids generates hydroxy-alkenals and oxidized phospholipids active in physiological and/or pathological conditions. Chem Phys Lipids 2009, 157, 1-11.

12. Celi P.: Oxidative stress in ruminants. In: Studies on veterinary medicine. Vol. 5, edited by L. Mandelker, P. Vajdovich, Humana Press, Totawa, 2011, pp. 191-231.

13. Erel O.: A novel automated direct measurement method for total antioxidant capacity using a new generation, more stable ABTS radical cation. Clin Biochem 2004, 37, 277-285. 
14. Erel O.: A new automated colorimetric method for measuring total oxidant status. Clin Biochem 2005, 38, 1103-1111.

15. Edmonson A., Lean I., Weaver L., Farver T., Webster G.: A body condition scoring chart for Holstein dairy cows. J Dairy Sci 1989, 72, 68-78.

16. Feldmann M., Tenhagen B.A., Emming S., Hoedemaker M.: Factors influencing the effect of treatment of chronic bovine endometritis. Dtsch Tierarztl Wochenschr 2005, 112, 10-16.

17. Gharagozlou F., Ghasemzadeh-Nava H,. Atyabi N., Sharifi Yazdi H., Akbarinejad V.: Evaluation of therapeutic effects of a 5-day intrauterine infusion of 6\% Eucalyptus globulus oil solution on mares with experimentally induced endometritis with Streptococcus zooepidemicus. Iranian J Vet Res 2014, 15, 145-148

18. Gilbert R.O., Shin S.T., Guard C.L., Erb H.N., Frajblat M.: Prevalence of endometritis and its effects on reproductive performance of dairy cows. Theriogenology 2005, 64, 1879-1888.

19. Gong J., Sun F., Li Y., Zhou X., Duan Z., Duan F., Zhao L., Chen H., Qi S., Shen J.: Momordica charantia polysaccharides could protect against cerebral ischemia/reperfusion injury through inhibiting oxidative stress mediated c-Jun N-terminal kinase 3 signaling pathway. Neuropharmacology 2015, 91, 123-134.

20. Gürbüz I., Akyuz C., Yesilada E., Sener B.: Anti ulcerogenic effect of Momordica charantia L. fruit on various ulcer models in rats. J Ethnopharmacol 2000, 71, 77-82.

21. Haimerl P., Heuwieser W., Arlt S.: Therapy of bovine endometritis with prostaglandin F2alpha: a meta-analysis. J Dairy Sci 2013, 96, 2973-2987.

22. Hanafi E.M., Ahmed W.M., Sherein I., El Moez A., El Khadrawy H.H., Amal R., El Hameed A.: Effect of clinical endometritis on ovarian activity and oxidative stress status in Egyptian buffalo-cows. Am-Eurasian J Agric Environ Sci 2008, 4, 530-536.

23. Harma M., Harma M., Erel O.: Measurement of the total antioxidant response in preeclampsia with a novel method. Eur $\mathrm{J}$ Obstet Gynecol Reprod Biol 2005, 118, 47-51.

24. Heidarpour M., Mohr1 M., Fallah-Rad A.H., Dehghan Shahreza F., Mohammadı M.: Oxidative stress and trace elements before and after treatment in dairy cows with clinical and subclinical endometritis. Rev Méd Vét 2012, 163, 628-633.

25. Hüntelmann C.: Investigation on the influence of time of postpartum examination and the initiation of a PGF $2 \alpha$ treatment of chronic endometritis in dairy cows. Thesis, Freie Universitat Berlin, Berlin, Germany. 2005,http://www.diss.fuberlin.de/ diss/servlets/MCRFileNodeServlet/FUDISS derivate 00000001 4219/Haimerl_online.pdf

26. Kaçar C., Atakisi E., Somali M., Kaya D., Zonturlu A.K., Kaya S., Gungor O., Aslan S.: Effectiveness of two different intrauterine and a conventional PGF2 alpha treatments on creatine kinase/aspartate aminotransferase levels and reproductive performance in cows with chronic endometritis. ESDAR 2010, Eger, Hungary. pp. 15-18.

27. Kasimanickam R., Duffield T.F., Foster R.A., Gartley C.J., Leslie K.E., Walton J.S., Johnson W.H.: Endometrial cytology and ultrasonography for the detection of subclinical endometritis in postpartum dairy cows. Theriogenology 2004, 62, 9-23.

28. Kaveh A.A., Ranjbari O., Mosaferi S.: The effect of intrauterine injection of super-oxidized water on the improvement of postpartum endometritis in dairy cows. Europ J Zoolog Res 2014, 3, 55-61.

29. Khillare K., Birade H.S., Maini S., Ravikanth K.: Role of polyherbal intrauterine infusion in treatment of various reproductive disorders in cattle. Vet World 2010, 3, 373-374.

30. Krawinkel M.B., Keding G.B.: Bitter gourd (Momordica charantia): a dietary approach to hyperglycemia. Nutr Rev 2006, 64, 331-337.

31. Krishnan B.B., Kumar H., Mehrotra S., Singh S.K., Goswamı T.K., Narayanan K.: Subclinical endometritis increases oxidative stress and modulates polymorphonuclear leukocyte functions in crossbred cows. Indian J Anim Sci 2014, 84, 1192-1195.

32. Kubola J., Siriamornpun S.: Phenolic contents and antioxidant activities of bitter gourd (Momordica charantia L.) leaf, stem, and fruit fraction extracts in vitro. Food Chem 2008, 110, 881-890.

33. Kucukaslan I., Kaya D., Emre B., Bollwein H., Ozyurtlu N., Mulazimoglu B., Aslan S.: Evaluation of endometrial echotexture and cervical cytology in cows during and after treatment of endometritis. Tierarztl Prax Ausg G Grosstiere Nutztiere 2014, 42, 343-350.

34. LeBlanc S.J., Duffield T.F., Leslie K.E., Bateman K.G., Keefe G.P., Walton J.S., JohnsonW.H.: Defining and diagnosing postpartum clinical endometritis and its impact on reproductive performance in dairy cows. J Dairy Sci 2002, 85, 2223-2236.

35. Li D.J., Feng Y.L., Fei L.Y., Ying L., Ying P.X., Zong G.D.: Significance of nitric oxide concentration in plasma and uterine secretes with puerperal endometritis in dairy cows. Vet Res Commun 2010, 34, 315-321.

36. Lykkesfeldt J., Svendsen O.: Oxidants and antioxidants in disease: oxidative stress in farm animals. Vet $\mathrm{J}$ 2007, 173, 502-511.

37. Melcher Y., Prunner I., Drillich M.: Degree of variation and reproducibility of different methods for the diagnosis of subclinical endometritis. Theriogenology 2014, 82, 57-63.

38. Minami Y., Islam M.R., Funatsu G.: Chemical modifications of momordica and luffina ribosome-inactivating proteins from the seeds of Momordica charantia and Luffa cylindrica: involvement of His140, Tyr165, and Lys231 in the protein-synthesis inhibitory activity. Biosci Biotechnol Biochem 1998, 62, 959-964.

39. Oishi Y., Sakamoto T., Udagawa H., Tanıguchı H., KobayashıHattorı K., Ozawa Y., Takıta T.: Inhibition of increases in blood glucose and serum neutral fat by Momordica charantia saponin fraction. Biosci Biotechnol Biochem 2007, 71, 735-740.

40. Oral H., Kuru M., Kulaksız R., Kaya S.: Kronik endometritisli ineklerde intrauterin uygulanan kekik yağının gebe kalma oranı üzerine etkisi. Lalahan Hay Araşt Ens Derg 2014, 54, 57-61.

41. Pandey R.K., Kumar P.: Drying kinetics of green bitter gourd (Momordica charantia L.) slices in a fluidized bed dryer. German National Library Verlag, Open Publishing GmbH. ISBN: 978-3-668-01149-6, 2015, p. 4.

42. Panda B.C., Mondal S., Devi K.S.P., Maiti T.K., Khatua S., Acharya K., Syed S.: Islam pectic polysaccharide from the green fruits of Momordica charantia (Karela): structural characterization and study of immunoenhancing and antioxidant properties. Carbohydr Res 2015, 401, 24-31.

43. Polat B., Cengiz M., Cannazika O., Colak A., Oruc E., Altun S., Salar S., Bastan A.: Endometrial echotexture variables in postpartum cows with subclinical endometritis. Anim Reprod Sci 2015, 155, 50-55.

44. Purohit G.N., Ruhil S., Khichar V.: Postpartum endometritis in dairy cows: current status of diagnosis, therapy and prevention. Theriogenology 2015, 5, 1-23.

45. Rao B.K., Kesavulu M.M., Apparao C.: Antihyperglycemic activity of Momordica cymbalaria in alloxan diabetic rats. J Ethnopharmacol 2001, 78, 67-71.

46. Sagor A.T., Chowdhury M.R.H., Tabassum N., Hossain H., Rahman M.M., Alam M.A.: Supplementation of fresh ucche (Momordica charantia L. var. muricata Willd) prevented oxidative stress, fibrosis and hepatic damage in $\mathrm{CCl} 4$ treated rats. BMC complement alternat med 2015, 15, 115 .

47. Sarma O.K., Singh B., Singh M.P., Tiwary B.K., Sinha M.P.: Efficacy of immunomodulators for treatment of endometritis in cows. Indian J Anim Reprod 2010, 31, 59-61.

48. Sheldon I.M, Lewis G.S., Leblanc S., Gilbert R.O.: Defining postpartum uterine disease in cattle. Theriogenology 2006, 65, $1516-1530$.

49. Sheldon I.M.: Endometritis in cattle: pathogenesis, consequences for fertility, diagnosis and therapeutic recommendations. Intervet - Reprod Manag Bull 2007, 2, 1-5. 
50. Svobodova B., Barros L., Calhelha R.C., Heleno S., Alves M.J., Walcott S., Bittova M., Kuban V.1,, Ferreira I.C.F.R.: Bioactive properties and phenolic profile of Momordica charantia L. medicinal plant growing wild in Trinidad and Tobago. Industrial Crops Prod 2017, 95, 365-373.

51. Şenüver A., Nak D.: İnfertilite. In: Çiftlik Hayvanlarında Doğum ve Jinekoloji, edited by Semecan A., Kaymaz M., Findik M., Rişvanli A., Köker A., Chapter 1, Topic 13, Malatya, Turkey, 2015, pp. 365-419.

52. Trevisan M., Browne R., Ram M., Muti P., Freudenheim J., Carosella A.M., Armstrong D.: Correlates of markers of oxidative status in the general population. Am J Epidemiol 2001,154, 348-356.

53. Wagener K., Gabler C., Drillich M.: A review of the ongoing discussion about definition, diagnosis, and pathomechanism of subclinical endometritis in dairy cows. Theriogenology 2017, 94, 21-30.

54. Wang S., Zheng Y., Xiang F., Li S., Yang G.: Antifungal activity of Momordica charantia seed extracts toward the pathogenic fungus Fusarium solani L. J Food Drug Anal 2016, 24, 881-887. 